\title{
Evaluating Soil Nutrient Regime for Black Spruce in the Ontario Claybelt by Fertilization ${ }^{1}$
}

\author{
by
}

\author{
V.R. Timmer, ${ }^{2}$ and P.N. Ray ${ }^{2}$
}

\section{Abstract}

Fertilization screening trials testing a standard NPK application were conducted in 29 mature black spruce stands growing on diverse Claybelt sites. The objective was to evaluate several methods of predicting soil nutrient regime, and validate a nutrientrelated ordination axis of the regional Forest Ecosystem Classification (FEC) system. Diagnosis by vector analysis of current needle responses in dry weight and macronutrient concentration and content suggested that of all nutrients added $\mathrm{N}$ was most limiting for black spruce growth. Potential fertilizer response was measured by the change in unit needle $\mathrm{N}$ uptake (content) occurring in the first season after treatment. Significant increases (as high as 63\% over the control) were detected in about half the trials suggesting that the stands were established on sites varying in soil fertility. Foliar $\mathrm{N}$ response was subsequently correlated against more rapid predictors of site productivity such as stand growth parameters, site index, stem analysis, and chemical analysis of unfertilized soil and foliage. Of these only measures of fall-sampled, current needle $\mathrm{N}$ content correlated adequately $(r=-0.72)$ with potential fertilizer response. This response factor was also significantly correlated $(r=0.71)$ with the coordinate values of the FECordination diagram indicative of site nutrient regime, supporting evidence that the axis reflects a continuum of soil $\mathrm{N}$ availability.

Key words: Nitrogen, foliar analysis, response prediction, site evaluation, forest fertilization, Picea mariana

\section{Résumé}

Des essais de fertilisation par criblage ont eu lieu dans le but de tester une application standard de NPK sur 29 peuplements à maturité d'épinettes noires de divers sites de la zone argileuse. L'objectif visé était d'évaluer diverses méthodes de prédiction du profil des éléments nutritifs du sol, et de valider un système d'ordonnées reliées aux éléments nutritifs pour le système régional de Classification des écosystèmes forestiers (CEF). Le diagnostique établi par l'analyse des réponses actuelles des aiguilles selon leur poids à l'état sec et la concentration et le contenu des macroéléments nutritifs suggèrent que de tous les éléments nutritifs ajoutés, l'azote est l'élément le plus limitatif de la croissance de l'épinette noire. La réponse possible de la fertilisation a été mesurée par rapport au changement de concentration (contenu) d'azote par poids unitaire d'aiguilles, au cours de la première saison après traitement. Des augmentations significatives (jusqu'à $63 \%$ par rapport aux témoins) ont été notées dans près de la moitié des essais, ce qui suggère que les peuplements croissaient sur des sites dont la fertilité variait. La réponse foliaire à l'azote a été par la suite mise en corrélation avec des prédicteurs plus rapides de la productivité du site tel les paramètres de croissance du peuplement, l'indice du site, l'analyse du tronc, et l'analyse chimique du sol et du feuillage non fertilisés. De toutes ces mesures, seul le contenu actuel d'azote des aiguilles selon un échantillonnage effectué à l'automne correspond adéquatement $(r=0.72)$ à la réponse possible de la fertilisation. Ce facteur de réponse était aussi significativement coirrélé $(r=0.71)$ aux valeurs des coordonnées du systèmes d'ordonnées CEF qui est un indice du profil des éléments nutritifs, ce qui prouve que le système réflète un continuum de disponibilité de l'azote du sol.

Mots clés: Azote, analyse foliaire, prédiction de la réponse, évaluation du site, fertilisation forestière, Picea mariana

\section{Introduction}

A key to the successful prescription of forest management is a reliable and critical assessment of the nutrient

1Paper given at the Canada-Ontario Joint Forestry Research Committee (COJFR) Symposium "Site classification in relation to forest management" Timmins, Ont. Aug. 1985

2Faculty of Forestry, University of Toronto, Toronto, Ont. M5S 1A1 status of the forest to be treated. The Forest Ecosystem Classification (FEC) for the Ontario Claybelt utilizes a twodimensional ordination related to soil nutrient and moisture regime to fractionate "operational groups" or landscape segments, each having an "identified range of vegetation and soil conditions and a probable response to specific management prescriptions" (Jones et al. 1983b). The ordination was based on detrended correspondence analysis 
(DECORANA; Hill and Gauch 1980), applied to vegetation composition data of the region, which derives mathematical coordinate values on several axes for each vegetation type. The first axis, accounting for the greatest variation, appeared to coincide with soil and site features indicative of available nutrient levels. The second axis, accounting for the next greatest trend in the vegetation data, similarly showed a meaningful gradient of soil moisture regime. These relationships have useful silvicultural applications for the FEC system and need validation.

The objective of the present study was to evaluate soil nutrient regime of black spruce (Picea mariana [Mill.] B.S.P.) by response to a standard fertilizer addition. The fertilization response was to be correlated with alternative measures of inherent site productivity, such as stand growth parameters, site index, stem analysis, and chemical analysis of soils or foliage to assess their reliability as more rapid predictors of soil nutrient status. The response factor would also be tested against corresponding coordinate values of the FEC-ordination axes to evaluate the associated nutrient and moisture gradients.

\section{Study Rational}

\section{Measurement of nutrient regime}

There are several means for assessing nutrient status of forest sites; each has inherent advantages and disadvantages. The methods include comparisons of: growth rates of stands or trees (reviewed by Jones 1969, Carmean 1975); vegetative composition, especially diversity and density of ground cover species (reviewed by Daubenmire 1976); and visual symptoms, soil analysis, foliar analysis, pot trials, and response to nutrient additions in the field (reviewed comprehensively by Leaf 1973 , Morrison 1974). Of these, the fertilizer field trial is undoubtedly the most reliable since it involves direct response measurement to nutrient addition. However, its major drawbacks are cost, skilled manpower, uniform areas and the long time required to detect growth responses (Stone 1973). Foliar analysis is relatively fast and inexpensive, and is usually favoured as the next best approach (Morrison 1974). Nevertheless, its reliability in circumstances of marginal or incipient deficiencies is limited, and interpretations can be confounded by dilution effects and nutrient interactions (van den Driessche 1979).

Timmer and Morrow (1984) proposed a screening approach to nutrient-response prediction that integrated foliar analysis with short-term fertilizer trials. This combines the directness and authenticity of field trails with the rapidity and low cost of foliar analysis without seriously impairing the reliability of results. Response assessment was based on the change in foliar composition during one growing season rather than longterm mensurational parameters, and involved less elaborate field testing than conventional fertilization trials. A "mini" plot version of this approach has been applied to lodgepole pine (Pinus contorta var. latifolia [Engelm.]) stands in the interior of British Columbia (Weetman and Fournier 1982). Because of time constraints, the screening approach of Timmer and Morrow (1984) offered the most reliable means of evaluating soil fertility. The strategy was to apply this method as the standard against which other more rapid techniques, such as site-index estimation, tree growth comparisons, soil testing, amd foliar chemical analysis would be compared.

\section{Reliability of foliar response index}

In screening trials, early growth and nutrient responses in foliage are used as a quick index of future stemwood response to fertilization (Timmer and Morrow 1984). Predictive reliability is dependent on how well change in foliar composition reflects fertilizer response. Additions to the supply of a limiting nutrient, such as $\mathrm{N}$, may alter the composition and morphology of tree shoots and branches by 1 ) raising foliar $\mathrm{N}$ concentrations which is usually associated with increased chlorophyll content of leaves leading to greater photosynthesis per unit of leaf area (Keay et al 1968, Brix 1971), 2) increasing size and weight of individual needles contributing to more leaf surface area (Mellor and Tregunna 1972, Gordon and Gatherum 1967) and hence total photosynthesis surface (Turner and Olson 1976, Miller and Miller 1976), 3) increasing number of needles or buds per shoot (Turner and Olson 1976, Miller and Miller 1976) which promotes potential photosynthesis unless associated with greater selfshading of leaves (Albrektson et al. 1977), 4) prolonging retention of annual needles (Turner and Olson 1976, Miller and Miller 1976) increasing the functional life of photosynthetic surfaces, and 5) extending of the growing season of foliage for some days or weeks (Armson 1966, Morrow and Timmer 1981) which increases seasonal photosynthetic activity. To a large extent, response in photosynthetic efficiency and capacity is reflected in the index by integrating two foliar parameters: nutrient concentration and mass in terms of change in needle nutrient content (see Timmer and Morrow 1984). This measure accounts for dilution effects, and correlates better with longterm growth response than change in concentration or dry weight alone.

Standardized sampling protocols for foliage would minimize possible confounding effects of prolonged needle retention and extended season of activity by collecting autumnal, current shoots well after the end of the growing season. Only current year's needles need be sampled because these correlate higher with growth response than older needles (Leyton and Armson 1955). Photosynthetic efficiency of needles may decline rapidly with age, and new needles contribute most to the total photosynthetic capacity of the tree (Clark 1961, Keay et al. 1968, Brix 1971). Current year's needles of black spruce were also found to display lowest overall between-tree-variation in element content, and were considered more reliable than older needles for estimating site quality and tree growth performance (Lowry 1970). As bud primordia are initiated in the previous year for most northern conifers, it is important that foliage sampling be conducted in the first growing season after fertilization, to avoid confounding of response estimates by a fertilizer-induced increase in needle number occurring in subsequent seasons. Foliage collection, sampling and analysis in this study were conducted with these considerations in mind.

\section{Selection of fertilizer treatment}

Obviously the standardized fertilizer treatment selected to screen stand response should involve the nutrient most limiting forest productivity. Nitrogen is the first element likely to be deficient in soils of the Boreal forest (Armson et al. 1975, Rennie 1972), and black spruce appears primarily responsive to $N$, and secondarily to P (Watt 1966, Alban and Watt 1981, Weetman et al. 1980, Krause 1981, Morrison and Foster 1979). To be safe, we followed the rationale of the Interprovincial Forest Fertilization Program (Weetman et al. 1976, 1987) by testing the three nutrients most likely to be deficient: N, P and K. The most limiting nutrient for each screening trial would be identified from first season needle collections utilizing vector analysis, a graphical diagnostic system (Fig. 1) described by Timmer and Stone (1978) and Timmer and Morrow (1984). Provided shoot growth is determinate (which holds for black spruce) the technique facilitates interpretation of foliar nutrient status by 


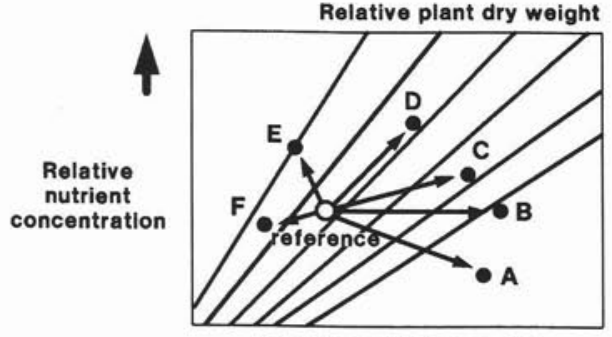

Relative nutrient content

\begin{tabular}{|c|c|c|c|c|c|}
\hline \multirow{3}{*}{$\begin{array}{c}\text { Direction } \\
\text { of shift }\end{array}$} & \multicolumn{3}{|c|}{ Change in relative } & \multirow[b]{3}{*}{ Interpretation } & \multirow{3}{*}{$\begin{array}{l}\text { Possible } \\
\text { Dlagnosis }\end{array}$} \\
\hline & \multirow{2}{*}{$\begin{array}{c}\text { Plant } \\
\text { welght }\end{array}$} & \multicolumn{2}{|c|}{ Nutrient } & & \\
\hline & & Conc. & \begin{tabular}{|l} 
Content \\
\end{tabular} & & \\
\hline $\begin{array}{l}\text { A } \\
\text { B } \\
\text { C } \\
\text { D } \\
\text { E } \\
\text { F }\end{array}$ & $\begin{array}{l}+ \\
+ \\
+ \\
0 \\
-\end{array}$ & $\begin{array}{l}- \\
0 \\
+ \\
+ \\
++ \\
-\end{array}$ & $\begin{array}{l}+ \\
+ \\
+ \\
+ \\
\pm \\
-\end{array}$ & $\begin{array}{l}\text { Dilution } \\
\text { Sufficiency } \\
\text { Deficiency } \\
\text { Luxury consump. } \\
\text { Excess } \\
\text { Excess }\end{array}$ & $\begin{array}{l}\text { Non-limiting } \\
\text { Non-limiting } \\
\text { Limiting } \\
\text { Non-toxic } \\
\text { Toxic } \\
\text { Antagonistic }\end{array}$ \\
\hline
\end{tabular}

Figure 1. Interpretation of directional relationships between nutrient concentration, absolute nutrient content, and dry weight of needles following treatment (adapted from Timmer and Stone 1978, Timmer and Morrow 1984).

identifying examples of dilution (A), sufficiency (B), deficiency (C), luxury consumption (D), toxicity (E) and possible antagonism (F) as a result of fertilization. Diagnostic interpretations assume a close correlation between needle weight and stem wood production in trees. Relative response in element concentration and absolute content of foliage are plotted against gain or loss in needle mass. In this manner, response patterns of nutrients are compared simultaneously on a common base by equalizing the control status to 100 . Interpretations are based on the orientation and magnitude of each response vector (arrow) in the nomogram (as shown in Fig. 1). The degree of responsiveness of added nutrients corresponds to the relative size of its vector.

\section{Experimental design}

The detection of significant growth response to fertilization in natural forests may often be masked by stand or site heterogeneity, experimentation commonly lacking the required replication. To overcome this problem, a single tree approach based on a "paired tree" design of Gagnon (1975) was adopted. Each screening trial consisted of a fertilized and adjacent unfertilized plot. Individual trees within plots acted as replicates since response measures were based on foliage rather than stemwood. Trees were paired between control and treatment plots in terms of diameter at breast height (DBH), height, and crown class as suggested by Gagnon (1975). Usually 8 pairs of sample trees were matched for each trial.

\section{Field Program, Laboratory Procedures and Data Analysis}

\section{Trial establishment}

During the field seasons of 1981-1982, 29 fertilizer trials were established in essentially mature black spruce stands in the Hearst, Kapuskasing and Cochrane districts of Ontario. Most of these stands were previously selected by field survey crews as part of an ongoing FEC program in the Claybelt (Jones et al. 1983b). Ten supplementary trials were set up in drier upland sites to extend representation to the widest possible spectrum of sites in the region. Each site was classified according to vegetation type and operational group following the procedures of Jones et al. (1983a). In each stand 2 adjacent
$10 \times 10 \mathrm{~m}$ plots were established with at least 1 -m buffers, plots being selected to match species composition, age structure, understory vegetation, basal area and density. All trees within the control plot were tallied for $\mathrm{DBH}$. Two to three dominant and codominant trees outside the plot perimeter were felled and sectioned at stump and breast height and at $1.2 \mathrm{~m}$ increments thereafter for stem analysis. Mensurational data from sample trees and control plots for each trial are summarized in Table 1.

\section{Fertilization}

The treatment plots received a standard fertilizer application in the spring of 1981 or 1982 . A granular fertilizer was broadcast manually over the forest floor. The plot area, including buffers, was subdivided into quarters. Quarter fractions of the total dosage were applied to each to ensure even distribution of fertilizer. Urea (45-0-0) was applied at $224 \mathrm{~kg} \mathrm{~N} / \mathrm{ha}$; triple superphosphate (0-45-0) and potassium chloride (0-0-61) were applied at $112 \mathrm{~kg} / \mathrm{ha}$ of $\mathrm{P}$ and $\mathrm{K}$, respectively.

\section{Soil and forest floor sampling}

Two randomly selected soil pits were dug in the control plot for soil-profile description and forest-floor characterization. Thickness of the effective rooting zone was recorded, and two composite soil samples from this zone were collected in the plot area. Each composite consisted of 10 cores taken at $1-\mathrm{m}$ intervals along a randomly chosen triangular transect. The samples were stored under refrigeration until laboratory analysis. Soil moisture and temperature measurements were undertaken on 20 plots established in 1982. In mid-summer, 4 core samples of known volume were taken from the forest floor to determine gravimetric moisture content. Four glass ampules filled with sucrose solution were buried at $10-\mathrm{cm}$ depth from late June to early October to serve as integrative temperature sensors. Mean growing season temperature of the forest floor was derived from the reaction velocity of sucrose hydrolosis as described by Lee (1969).

\section{Foliage sampling}

Samples of current and year-old foliage were collected by shotgun or extension pole pruner from the top-third of paired trees following Lowry's (1970) protocol. Foliage was sampled in the fall (November) of the year of fertilization when nutrient levels are generally stable. Samples were stored refrigerated until analyzed.

\section{Laboratory analysis}

Soil: Chemical analysis was done on both the mineral horizons and organic layers. The soils were air-dried and sieved. The following analytical methods were employed: 1) $\mathrm{pH}$ by soil water paste method, 2) organic C by the Walkley-Black method (Allison et al. 1965) for mineral soils, and by loss-on-ignition for organic soils, 3) total $\mathrm{N}$ by semi-micro Kjeldahl digestion and distillation (Bremner 1965).

Incubation experiments: Both forest floor and mineral soil samples were analyzed for mineralizable $\mathrm{N}$ by incubation. Samples were incubated anerobically at $30^{\circ} \mathrm{C}$ for 2 weeks (Waring and Bremner 1964). Nitrogen mineralized at the end of the period was extracted by $3 \mathrm{M} \mathrm{KCl} \mathrm{according} \mathrm{to} \mathrm{the} \mathrm{procedure}$ modified for forest soils by $\bar{P}$ owers (1980). Ammonium and nitrate nitrogen present in the extracts after incubation were determined by ammonia electrode following the method of Seigel (1980). 
Table 1. Mean height, age, density, basal area, and diameter of black spruce growing on the study sites.

\begin{tabular}{rrrccc}
\hline $\begin{array}{c}\text { Trial } \\
\text { no. }\end{array}$ & $\begin{array}{c}\text { Height } \\
(\mathbf{m})\end{array}$ & $\begin{array}{c}\text { Age } \\
(\mathbf{y r})\end{array}$ & $\begin{array}{c}\text { Basal area } \\
\left(\mathbf{m}^{2} / \mathbf{h a}\right)\end{array}$ & $\begin{array}{c}\text { Number of } \\
\text { trees/ha }\end{array}$ & $\begin{array}{c}\text { Average dbh } \\
(\mathbf{c m})\end{array}$ \\
\hline 29 & 11.10 & 105 & 26.70 & 2250 & 12.04 \\
31 & 6.30 & 60 & 14.00 & 700 & 8.00 \\
81 & 12.05 & 148 & 15.65 & 765 & 15.76 \\
92 & 9.40 & 149 & 10.42 & 850 & 12.49 \\
93 & 11.10 & 135 & 22.00 & 1600 & 13.07 \\
96 & 14.00 & 117 & 46.99 & 3000 & 13.18 \\
123 & 15.40 & 90 & 23.48 & 1600 & 13.92 \\
124 & 15.80 & 93 & 34.30 & 2700 & 12.56 \\
143 & 15.60 & 122 & 41.21 & 2100 & 15.21 \\
145 & 13.40 & 112 & 50.57 & 3200 & 13.89 \\
148 & 16.68 & 113 & 46.16 & 1800 & 17.56 \\
149 & 18.02 & 94 & 35.36 & 1600 & 16.38 \\
150 & 7.42 & 90 & 2.54 & 250 & 11.30 \\
152 & 12.66 & 108 & 12.36 & 800 & 13.85 \\
159 & 17.40 & 79 & 48.43 & 2600 & 15.00 \\
165 & 15.90 & 86 & 39.01 & 3100 & 12.48 \\
168 & 16.79 & 85 & 40.32 & 1700 & 15.38 \\
171 & 14.65 & 81 & 47.78 & 3100 & 13.81 \\
174 & 14.90 & 74 & 49.88 & 3700 & 12.91 \\
179 & 12.80 & 85 & 24.82 & 2100 & 12.12 \\
501 & 16.10 & 87 & 34.09 & 2900 & 11.93 \\
503 & 20.19 & 90 & 45.57 & 2400 & 15.08 \\
504 & 20.27 & 87 & 44.68 & 2800 & 14.29 \\
507 & 18.65 & 157 & 48.51 & 3100 & 13.68 \\
508 & 15.75 & 75 & 49.14 & 5100 & 10.75 \\
509 & 16.20 & 76 & 67.07 & 4800 & 13.12 \\
510 & 12.72 & 80 & 49.89 & 4700 & 11.32 \\
511 & 15.92 & 76 & 39.99 & 6900 & 8.20 \\
512 & 13.00 & 72 & 42.47 & 6000 & 9.00 \\
\hline & & & & &
\end{tabular}

a/mean of 2-4 trees/plot

Foliage: Weights of both old and new needle samples were determined in the following procedure: Current year's shoots were separated from old shoots of the sampled branches and dried in a force-draft oven. Oven dried needles were separated from the shoots and 2 sets of 100 randomly chosen needles in good condition were oven dried again at $65^{\circ} \mathrm{C}$. Drying was continued until the samples recorded constant weight. After dry-matter determination, the remaining current year's needle samples were ground through a Wiley mill. A quantity of this tissue material was dry ashed in a muffle furnace and then dissolved in $1 \mathrm{M} \mathrm{HCl}$. Phosphorus in this extract was determined colorimetrically by the molybdenum blue method and $\mathrm{K}, \mathrm{Ca}$ and $\mathrm{Mg}$ were determined by atomic absorption. Total $\mathrm{N}$ concentration in ground foliage was determined by semi-micro Kjeldahl digestion and distillation (Bremner 1965)

\section{Stem analysis}

Stem analysis was conducted on tree discs sectioned in the field. Measurements were made with a DIGI-MIC computer-assisted tree ring measurement instrument described by Jordan and Ballance (1983). Growth patterns of individual trees were generated in graphical form using a stem analysis plotting program (SAPP) specially developed for this study (Timmer and Verch 1983). The computer-drawn height / age curves yielded actual site index estimation, and provided the base data for construction of polymorphic site index curves for operational groups as classified by the FEC system (Ray 1984, unpublished report). The complete set of curves also facilitated quantitative comparisons of tree growth characteristics, such as height and volume development at early suppression, at index age, and over the most recent 30 yr period.

\section{Statistical analysis}

Statistical analyses were conducted on an IBM 360 computer using the Statistical Analysis System (SAS Institute Inc. 1982). Foliar response of dry weight and nutrient content of each trial were subject to analysis of variance. Where appropriate, covariance analysis using year-old needle dry weight as the covariate was employed. Fertilizer response was tested against variables of stand growth, stem analysis, and soil and foliar analysis using linear correlation procedures. Stepwise regression was performed to assess the predictive ability of the variables.

\section{Results and Discussion}

\section{Needle response to fertilization}

The average response (treated value minus control value) in oven dry weight of current year's foliage in the first season after fertilization ranged between -233 and $+551 \mu \mathrm{g} /$ needle over the 29 trials (Table 2). This variation reflects the broad range of stand and site conditions selected for the study. Despite large differences among trials, the analysis of variance of treatment response within trials revealed only 2 significant increases in needle weight, whereas none of the observed decreases was significant. Variability was less pronounced when nutrient responses were examined, as shown for foliar $\mathrm{N}$ content where 14 out of 29 trials exhibited significant increases (Table 2). The mixed NPK addition stimulated foliar uptake (content) of $\mathrm{N}$ as high as $9.6 \mu \mathrm{g} /$ needle or $63 \%$ over untreated levels. Phosphorous and $\mathrm{K}$ uptake increased significantly in only 7 and 2 stands, respectively (Ray 1985).

Table 2. First season response in dry weight and absolute $\mathbf{N}$ content of current year's needles of black spruce to fertilization treatment.

\begin{tabular}{|c|c|c|c|c|}
\hline $\begin{array}{l}\text { Trial } \\
\text { no. }\end{array}$ & $\begin{array}{c}\text { Vegetation } \\
\text { type }^{\text {a/ }}\end{array}$ & $\begin{array}{l}\text { Operational } \\
\text { group }^{\mathrm{a} /}\end{array}$ & $\begin{array}{c}\text { Unit dry weight } \\
(\mu \mathrm{g})\end{array}$ & $\begin{array}{c}\text { Foliar } \mathbf{N} \\
(\mu \mathrm{g} / \text { needle })\end{array}$ \\
\hline 29 & 2 & 2 & 69.87 & $7.70^{*}$ \\
\hline 31 & 2 & 2 & 45.15 & 2.78 \\
\hline 81 & 13 & 13 & 42.17 & 4.63 \\
\hline 92 & 9 & 11 & -52.25 & 5.28 \\
\hline 93 & 11 & 12 & 76.75 & $5.39^{\star}$ \\
\hline 96 & 11 & 11 & -63.58 & $4.39^{*}$ \\
\hline 123 & 7 & 4 & $214.25^{\star}$ & $7.73^{\star}$ \\
\hline 124 & 7 & 4 & -7.75 & $6.03^{\star}$ \\
\hline 143 & 7 & 4 & -63.13 & 4.20 \\
\hline 145 & 13 & 9 & 348.37 & $7.98^{\star}$ \\
\hline 148 & 9 & 12 & 053.88 & 3.68 \\
\hline 149 & 9 & 12 & 112.84 & $0.29^{*}$ \\
\hline 150 & 12 & 14 & 19.00 & $6.55^{\star}$ \\
\hline 152 & 9 & 12 & 97.87 & $9.43^{\star}$ \\
\hline 159 & 7 & 5 & 105.26 & 7.20 \\
\hline 165 & 7 & 5 & 187.25 & $7.79^{*}$ \\
\hline 168 & 13 & 13 & -141.87 & 1.23 \\
\hline 171 & 7 & 5 & 233.63 & $9.03^{\star}$ \\
\hline 174 & 17 & 9 & 133.13 & 4.09 \\
\hline 179 & 13 & 9 & -201.50 & 2.56 \\
\hline 501 & 4 & 3 & -217.58 & 2.47 \\
\hline 503 & 18 & 7 & -232.87 & 6.54 \\
\hline 504 & 17 & 9 & 239.75 & $9.39^{*}$ \\
\hline 507 & 7 & 8 & -74.12 & 5.57 \\
\hline 508 & 7 & 5 & $550.87^{\star}$ & $9.63^{*}$ \\
\hline 509 & 7 & 4 & 79.47 & -4.16 \\
\hline 510 & 7 & 4 & 151.88 & $8.63^{*}$ \\
\hline 511 & 7 & 5 & -129.13 & -7.50 \\
\hline 512 & 23 & 6 & 303.00 & -8.87 \\
\hline
\end{tabular}

*significant at 0.50 level

${ }^{a}$ classified according to Jones et al. (1983a) 


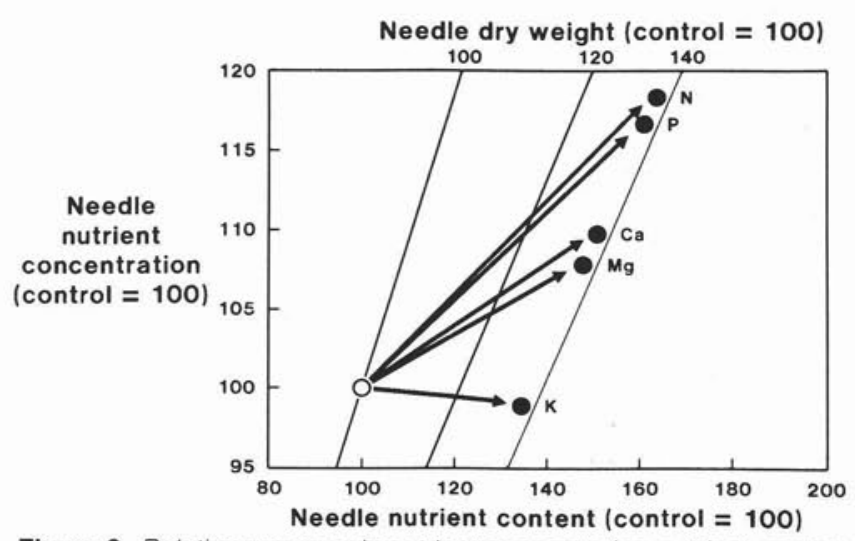

Figure 2. Relative response in nutrient concentration, nutrient content and dry weight of current foliage sampled from the most responsive trial (508) one growing season after fertilization. Control values (open symbol) were equalized to 100 to allow comparisons of different nutrients on a common base.

The effect of fertilization on the foliage of the most responsive trial (508) in terms of dry matter production is shown in Fig. 2 to demonstrate vector diagnosis. Since abundance of individual nutrients varies in foliage, control status was adjusted to 100 . Treatment increased needle mass $38 \% ; \mathrm{N}, \mathrm{P}, \mathrm{Ca}, \mathrm{Mg}$ and $\mathrm{K}$ concentration $18,16,10,7$ and $-2 \%$, and content 63,59 , 50,47 and $36 \%$, respectively. Nitrogen exhibited the largest response (vector) into the zone of deficiency which is characterized by positive changes in foliar dry weight, nutrient concentration and nutrient content (shift $\mathrm{C}$ ) while $\mathrm{K}$ status was slightly diluted (positive, negative and positive response in respective dry weight, concentration and content, shift $A$ ). Interpretations based on vector length and the diagnostic guide of Fig. 1 suggest that of all nutrients tested (in Figure 2) N was the first limiting, followed by $\mathrm{P}, \mathrm{Ca}$ and $\mathrm{Mg}$. This ranking was similar to the averaged needle response of all screening trials (Ray 1985), and confirmed the initial assumptions that $N$ and $P$ were the primary and secondary growth-limiting elements, respectively. On this basis, subsequent response analysis focused on $\mathrm{N}$ rather than the other macronutrients applied.

Relative responses in needle dry weight and $\mathrm{N}$ composition of all 29 trials are shown schematically in Fig. 3. The diagnonals represent increments of unit needle weights, thus shifts along the reference diagonal (100) depict no real change in needle mass, those to the left or right signified gain or loss respectively. Graphical diagnosis according to Fig. 1 suggest N deficiency in 16 of the trials, because fertilization was associated with positive shifts in all three needle parameters (shift C). Comparative deficiency between stands is reflected in the abscissa since needle $\mathrm{N}$ content is a more sensitive index of long-term fertilizer growth response than dry weight (Timmer and Morrow 1984). Ten trials exhibited increased foliar $N$ without gain in dry mass suggesting that the extra $N$ taken up probably contributed to luxury (shift D) or excess (shift E) consumption. Nitrogen uptake was reduced by only 3 stands, demonstrating possible dilution (shift A) or antagonistic (shift F) effects from treatment. In fact, individual vector analysis of trials 509 and 512 revealed that $P$ and $K$ were the first limiting nutrients, respectively (Ray 1985).

\section{Correlating fertilizer response against tree growth, soil, and foliage parameters}

Table 3 gives the simple correlations of foliar $\mathrm{N}$ response (potential fertilizer response) against more rapid indices of site

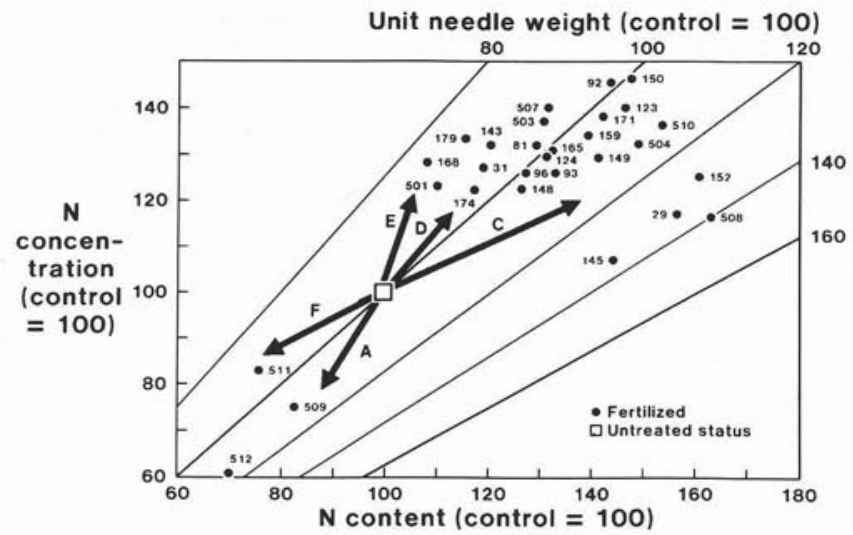

Figure 3. Relative response in foliar $\mathrm{N}$ concentration, $\mathrm{N}$ content and dry weight of screening trials to a standard fertilizer application. Control plots were adjusted to 100 to allow comparisons of different stands on a common base. Magnitude and direction of response vector indicate occurrence of dilution (A), deficiency (C), luxury (D) and excess $(E)$ consumption and possible antagonism ( $F$ ).

nutrient regime. In general, the correlations were weak with growth parameters derived from stand measures or stem analysis of individual trees, probably because tree growth performance is influenced by other factors in addition to nutrients. In older and denser stands crown expansion can be restricted after fertilization (Strand and DeBell 1979), which may reflect the significant inverse correlation found between fertilizer response and stand density.

It is interesting to note that, although not statistically significant, site index adjusted for initial growth suppression exhibited higher correlations than that based on actual site index, and that periodic height growth of the last 30 years showed stronger correlations than that based on the initial 50 years. These results illustrate improved precision by accounting for early growth development not related to soil fertility. Site index values determined from anamorphic curves (Plonski 1974, Payandeh 1973) were found to be poorly correlated with fertilizer response, and lacked improvement when derived from polymorphic curves (developed by Ray [1984], unpublished report). Results parallel the findings of Krause et al. (1982) with black spruce where site index did not correlate significantly with fertilization response.

Foliar $\mathrm{N}$ response was not significantly correlated with any of the soil variables. This outcome is disappointing since chemical and environmental factors such as carbon source, $\mathrm{pH}$, moisture and temperature conditions tend to govern soil $\mathrm{N}$ mineralization processes (Wollum and Davey 1975). These were in turn expected to influence fertilizer response. Higher correlations may have been obscured by pronounced lateral variability of chemical parameters in forest floors (Arp and Krause 1984), and by the need for more intensive sampling.

Foliar parameters of the unfertilized control plots correlated better with response estimates than any of the other variables in Table 3. Of all nutrients analyzed only $\mathrm{N}$ was correlated significantly and inversely with potential fertilizer response. This was expected since vector diagnosis indicated $\mathrm{N}$ to be the most limiting nutrient for many of these stands. Absolute rather than relative amounts of $\mathrm{N}$ in needles correlated stronger with fertilizer response (-0.72 vs -0.53$)$, and both recorded higher correlation coefficients than needle dry weight $(-0.50)$. Initial foliar $\mathrm{N}$ content accounted for about $52 \%$ of the observed 
Table 3. Linear correlation coefficient $(r)$ between first season relative response in foliar $\mathrm{N}$ content and variables of stand growth, stem analysis, soil, and foliage.

\begin{tabular}{|c|c|c|c|c|}
\hline Variable & $r$ & n & Mean & $(S D)^{a /}$ \\
\hline $\begin{array}{l}\text { Stand growth } \\
\text { Site index (Plonski), m } \\
\text { Site index (polymorphic), m } \\
\text { Mean dbh, cm } \\
\text { Basal area, } \mathrm{m}^{2} / \mathrm{ha} \\
\text { Trees/ha }\end{array}$ & $\begin{array}{l}-0.21 \\
-0.22 \\
0.31 \\
-0.27 \\
-0.49^{*}\end{array}$ & $\begin{array}{l}29 \\
29 \\
29 \\
29 \\
29\end{array}$ & $\begin{array}{r}9.1 \\
9.4 \\
13.1 \\
36.3 \\
2600\end{array}$ & $\begin{array}{l}(3.2) \\
(2.6) \\
(2.2) \\
(5.5) \\
(1542)\end{array}$ \\
\hline $\begin{array}{l}\text { Stem analysis }{ }^{\mathrm{b} /} \\
\text { Height at } 50 \text { yrs } \\
\text { (site index, } \mathrm{SI}), \mathrm{m} \\
\text { Adjusted } \mathrm{SI} \text { (for suppression), } \\
\mathrm{m} \\
\text { Height growth last } 30 \mathrm{yrs}, \mathrm{m} \\
\text { Volume at } 50 \mathrm{yrs}, \mathrm{dm}^{3} \\
\text { Maximum current annual } \\
\text { volume increment, } \mathrm{dm}^{3}\end{array}$ & $\begin{array}{l}-0.17 \\
-0.23 \\
-0.37 \\
-0.06 \\
-0.14\end{array}$ & $\begin{array}{l}29 \\
29 \\
29 \\
29\end{array}$ & $\begin{array}{r}9.1 \\
9.3 \\
4.6 \\
42.8 \\
4.9\end{array}$ & $\begin{array}{l}(3.3) \\
(2.8) \\
(1.5) \\
(3.5) \\
(2.5)\end{array}$ \\
\hline $\begin{array}{l}\text { Soil factors }{ }^{\mathrm{c} /} \\
\mathrm{pH} \\
\text { Gravimetric moisture } \\
\text { content, \% } \\
\text { Mean growing season } \\
\text { temperature, }{ }^{\circ} \mathrm{C} \\
\text { Total } \mathrm{N}, \% \\
\text { Mineral } \mathrm{N}, \mathrm{ppm} \\
\text { Organic } \mathrm{C}, \% \\
\mathrm{C} / \mathrm{N} \text { ratio }\end{array}$ & $\begin{array}{l}-0.10 \\
0.07 \\
0.18 \\
0.08 \\
0.12 \\
0.14 \\
0.07\end{array}$ & $\begin{array}{l}20 \\
17 \\
29 \\
29 \\
29 \\
29\end{array}$ & $\begin{array}{c}3.8 \\
47.0 \\
13.7 \\
1.1 \\
342 \\
28.1 \\
27.1\end{array}$ & $\begin{array}{l}(0.7) \\
(20) \\
(1.5) \\
(0.4) \\
(179) \\
(5.7) \\
(6.7)\end{array}$ \\
\hline $\begin{array}{l}\text { Foliar parameters }{ }^{\mathrm{d} /} \\
\text { Dry weight, } \mathrm{mg} / \text { needle } \\
\mathrm{N} \text { content, } \mu \mathrm{g} / \text { needle } \\
\mathrm{N} \text { concentration, \% } \\
\mathrm{P} \text { concentration, \% } \\
\mathrm{K} \text { concentration, \% } \\
\text { Ca concentration, \% } \\
\mathrm{Mg} \text { concentration, \% }\end{array}$ & $\begin{array}{l}-0.50^{\star} \\
-0.72^{\star} \\
-0.53^{\star} \\
-0.17 \\
0.27 \\
-0.15 \\
-0.00\end{array}$ & $\begin{array}{l}29 \\
29 \\
29 \\
28 \\
28 \\
28 \\
28\end{array}$ & $\begin{array}{c}1.73 \\
18.6 \\
1.05 \\
0.13 \\
0.45 \\
0.49 \\
0.12\end{array}$ & $\begin{array}{l}(0.31) \\
(4.78) \\
(0.18) \\
(0.03) \\
(0.05) \\
(0.07) \\
(0.01)\end{array}$ \\
\hline
\end{tabular}

"significant at 0.05 level

a/standard deviation

b/derived from stem analysis (SAPP) graphs

$\mathrm{c}$ depth of effective rooting zone

d/current year's needles from control trees

variation in fertilizer response for all sites, and the degree of responsiveness increased with declining $\mathrm{N}$ status.

A stepwise regression applied to all variables indicated that only absolute needle $\mathrm{N}$ content accounted significantly and adequately $(<50 \%)$ for the foliar response to fertilization, and appears to be the only variable that can predict potential fertilizer response or soil nutrient regime with reasonable precision. As an index, its determination is considerably faster and less costly compared with the foliar response approach employed as the standard for this study (i.e. fertilizer applications followed by foliar response measurements). To ensure consistency and comparability, it is important that the standardized sampling protocol for collecting black spruce foliage established by Lowry (1970) be followed. Laboratory procedures would involve routine chemical analysis for $\mathrm{N}$, and the additional step of determining needle dry weight on a unit basis is essential. Expression of absolute foliar $\mathrm{N}$ content should not be confused with the more common measure expressed as a concentration. Concentration values correlated less with estimated fertilizer response than content values (Table 3).

\section{Evaluation of FEC nutrient axes}

The responses in current year's foliar $N$ content of individual stands were averaged by vegetation type (Table 2)
Table 4. Linear correlation between relative response in foliar $\mathbf{N}$ content (averaged by vegetation type) and DECORANA ordination values of corresponding FEC-vegetation types.

\begin{tabular}{lcc}
\hline Variable $^{\mathrm{a} /}$ & Associated trend & $\mathbf{r}$ \\
\hline Axis 1 & nutrients & $0.71^{*}$ \\
Axis 2 & moisture & -0.25 \\
Axis 1 x Axis 2 & interaction & 0.07 \\
\hline
\end{tabular}

"significant at 0.05 level

a/Jones et al. (1983b), for details of analysis see Ray (1985)

and tested against their axis-1 and axis-2 DECORANA coordinate values shown in Jones et al. (1983b, Fig. 3). It should be pointed out here that the axes labels of the DECORANA ordination diagrams in Jones et al. (1983b) were inadvertently exchanged, so that the horizontal axis-1 was incorrectly labelled "axis-2" and the vertical axis-2 was incorrectly labelled "axis-1" (Pierpoint 1987, personal communication). Although only 9 out of 23 vegetation types were represented in this analysis, Table 4 shows that a significant positive correlation $(r=0.71)$ was obtained with the axis-1 values indicative of soil nutrient regime. Fertilizer response was not well correlated with axis-2 values (inferring soil moisture regime) nor with the interaction of the two axes, which may indicate that degree of variation explained by the second axis individually is much less than that by the first axis. The data are limited by low representation and small sample size, but suggest that the first axis of the Claybelt FEC-ordination diagram reflects a continuum of soil $\mathrm{N}$ availability.

\section{Conclusion}

Vector diagnosis of first-year foliar response in black spruce fertilized with mixed NPK on a variety of soil and vegetation types indicated that $\mathrm{N}$ was often the major nutrient limiting productivity. Increased needle uptake of this element suggests that approximately half of the stands would respond positively to treatment. Pre-fertilization $\mathrm{N}$ status of fall-sampled current year's foliage (determined as $\mathrm{mg} \mathrm{N} /$ needle) correlated best with potential fertilizer response and may serve as a faster and less costly means of evaluating soil fertility. The potential fertilizer response averaged by vegetation type also correlated significantly with first axis coordinates of the Claybelt FECordination diagram, and tends to support evidence that this axis is associated with a gradient of soil nutrient regime. The results have bearing on the utility of foliar $\mathrm{N}$ analysis and FEC-derived indices in prescribing management practices for black spruce. In developing fertilizer guidelines for forestry, Weetman et al. (1987) note that the complex task of actual stand level response prediction can be made less uncertain if the initial step of nutrient deficiency diagnosis of recognized forest types is based on established and properly calibrated site evaluation systems. It is recommended that the correlations that have emerged in this study be confirmed by more extensive independent field testing.

\section{Acknowledgements}

This research was supported by funds from the Ontario Ministry of Natural Resources and Canada Department of Regional Economic Expansion. The authors are grateful to G. Pierpoint, Ontario Ministry of Natural Resources for review and advice for this project.

\section{References}

Alban, D.H. and R.F. Watt. 1981. Fertilization of black spruce on poor site peatland in Minnesota. USDA For. Serv. Res. Paper NC-210.

Albrektson, A., A. Aronsson, and C.O. Tamm. 1977. The effect of forest fertilization on primary production and nutrient cycling in the forest ecosystem. Silva Fennica. 11: 233-239. 
Allison, L.E., W.B. Bollen, and C.D. Modie. 1965. Organic carbon. In Methods of Soil Analysis. C.A. Black (ed.). Agronomy No. 9 p. 1346-1365.

Armson, K.A. 1966. The growth and absorption of nutrients by fertilized and unfertilized white spruce seedling. For. Chron. 42: 127-136

Armson, K.A., H.H. Krause and G.F. Weetman. 1975. Fertilization response in the northern coniferous forest. In: Forest Soils and Forest Land Management. B. Bernier and C.H. Winget, (eds.) Univ. Laval Press, Quebec. p. 449-460.

Arp, P.A. and H.H. Krause. 1984. The forest floor: (lateral variability as revealed by systematic sampling. Can. J. Soil Sci. 64: 423-437.

Bremner, J.M. 1965. Total nitrogen. In: Methods of Soil Analysis. C.A Black (ed.) Agronomy No. 9. p. 1149-1176

Brix H. 1971. Effects of nitrogen fertilization on photosynthesis and respiration in Douglas fir. For. Sci. 17: 407-414

Carmean, W.H. 1975. Forest site quality evaluation in the United States. Adv. Agronomy. 27: 209-269.

Clark, J. 1961. Photosynthesis and respiration in white spruce and balsam fir. State Univ. Col. of For. Tech. Pub. No. 85

Daubenmire, R. 1976. The use of vegetation in assessing the productivity of forest lands. Bot. Rev. 42: 115-143.

Gagnon, J.D. 1975. A quick and simple method to assess yearly diameter growth response to fertilization in natural forest stands. Can. For. Serv. Bi-monthly Res. Notes. 31:25-26.

Grodon, J.C. and G.E. Gatherum. 1967. Correlations among fresh weight, dry weight, volume and total length of needles of Scotch pine seedlings. For. Sci. 13: 426-427

Hill, M.O. and H.G. Gauch. 1980. Detrended correspondence analysis, an improved ordination technique. Vegetatio. 42: 47-58

Jones, J.R. 1969. Review and comparison of site evaluation methods USDA For. Serv. Res. Pap. RM-51.

Jones R.K., G. Pierpoint, G.M. Wickware, J.K. Jeglum, R.W. Arnup and J.M. Bowles. 1983a. Field guide to forest ecosystem classification for the Clay Belt, Site Region 3E. Ont. Min. Nat. Res., Toronto

Jones, R.K., G. Pierpoint, G.M. Wickware and J.K. Jeglum. 1983b. A classification and ordination of forest ecosystems in the Great Claybelt of Northeastern Ontario. In: R. Weine (ed.) Proc. Resources and Dynamics of the Boreal Zone. Assoc. Can. Univ. for N. Studies. p. 83-96

Jordan, G.A. and R.H. Ballance. 1983. A microcomputer-based annual ring measurement system. For. Chron. 59: 21-25.

Keay, J., A.G. Turton and N.A. Campbell. 1968. Some effects of nitrogen and phosphorus fertilization on Pinus pinaster in Western Australia. For. Sci. 14: 408-417

Krause, H.H. 1981. Factorial experiments with nitrogen phosphorus and potassium fertilizers in spruce and fir stands of New Brunswick: 10-year results. Dept. Env. Can. For. Serv. Inform. Rep. M-X-123.

Krause, H.H., G.F. Weetman, E. Koller and J.M. Veilleux. 1982. Interprovincial forest fertilization program: results of five-year growth remeasurements. Can. For. Serv. Inf. Rep. DPC-X-12.

Leaf, A.L. 1973. Plant analysis as an aid in fertilizing forests. In: Soil Testing and Plant Analysis. Walsh, L.M. and J.D. Beaton (eds.). Soil Sci. Soc. Am. Madison, Wis. p. 426-454

Lee, R. 1969. Chemical temperature integration. J. App. Meteorol. 8: 423-430

Leyton, L. and K.A. Armson. 1955. Mineral composition of the foliage in relation to the growth of Scots pine. For. Sci. 1:210-218.

Lowry, G.L. 1970. Variations in nutrients of black spruce needles. In: C.T. Youngberg and C.B. Davey (eds.). Tree Growth and Forest Soils. Oreg. State Univ. Press, Corvallis. p. 235-259.

Mellor, C.E. and E.B. Tregunna. 1972. The relationship between leaf area and leaf dry weight of three conifer species grown on three sources of nitrogen. Can. J. For. Res. 2: 377-379.

Miller, H.G. and J.D. Miller. 1976. Analysis of needle fall as a means of assessing nitrogen status in pine. For. 49: 57-61

Morrison, I.K. 1974. Mineral nutrition of conifers with special reference to nutrient status interpretation: A review of literature. Can. For. Serv. Pub. No. 1343.

Morrison, I.K. and N.W. Foster. 1979. Five-year growth in two nitrogen-phosphorous fertilization experiments in spruce-fir upland forest in northern Ontario. Can. For. Serv., Great Lakes For. Res. Cent. Inf. Rep. 0-X-299.
Morrow, L.D. and V.R. Timmer. 1981. Intraseasonal growth and nutrient composition of jack pine needles following fertilization. Can. J. For. Res. 11: 696-702

Payandeh, B. 1973. Plonski's yield tables formulated. Can. For. Serv. Dept. Environ. Pub. 1318

Plonski, W.L. 1974. Normal yield tables (metric) for major forest species of Ontario. Ont. Min. Nat. Resour. Toronto

Powers, R.F. 1980. Mineralizable soil nitrogen as an index of nitrogen availability to forest trees. Soil Sci. Soc. Am. J. 44: 1314-1320

Ray, P.N. 1985. An approach to evaluating site productivity response for black spruce (Picea mariana [Mill.] B.S.P.) of the Ontario Claybelt. Ph.D. Thesis, Univ. Toronto, Canada

Rennie, P.J. 1972. Forest fertilization in Canada. In: Proc. VIIth World For. Cong., Tech. Comm 1, Buenos Aires, Argentina.

SAS Institute Inc. 1982. SAS user's guide: Statistics. SAS Inst., Inc. Raleigh, N.C.

Seigel, R.S. 1980. Determination of nitrate and exchangeable ammonium in soil extracts by an ammonium electrode. Soil Sci. Soc. Amer. J. 44: 943-947

Stone, E.L. 1973. Regional objectives in forest fertilization: current and potential. In: Forest Fertilization Symposium Proc. USDA For. Serv. Gen. Tech. Bull. NE-3. p. 10-18

Strand, R.F. and D.S. DeBell. 1979. Growth response to fertilization in relation to stocking levels of Douglas fir. In: S.P. Gessel et al. (eds.) Proc. Forest Fertilization Conference, Inst. For. Resour Univ. Washington, Seattle. Cont. No. 40, p. 102-106.

Timmer, V.R. and E.L. Stone. 1978. Comparative foliar analysis of young balsam fir fertilized with nitrogen, phosphorus, potassium, and lime. Soil Sci. Soc. Am. J. 42: 125-130.

Timmer, V.R. and L.D. Morrow. 1980. Preliminary growth response and fertilizer diagnosis of fertilized jack pine and black spruce plantations in the Lake Nipigon-Beardmore areas. Contract Report, O.M.N.R.

Timmer, V.R. and L.D. Morrow. 1984. Predicting fertilizer growth response and nutrient status of jack pine by foliar diagnosis. In: Forest Soils and Treatment Impact. E.L. Stone (ed.). Proc. 6th North Amer. Forest Soils Conf. Univ. Tenn. Knoxville. p 335351

Timmer, V.R. and B.R. Verch. 1983. SAPP: A computer program for plotting stem analysis. For. Chron. 59: 298-303

Turner, J. and P.R. OIson. 1976. Nitrogen relations in a Douglas-fir plantation. Ann. Bot. 40: 1185-1193.

van den Driessche, R. 1979. Estimating potential response to fertilizer based on tree tissue and litter analysis. In: S.P. Gesse et. al. (eds.) Proc. Forest Fertilization Conference. Inst. For Resour. Univ. Washington, Seattle. Cont. No. 40. p. 214-220.

Waring, S.A. and J.M. Bremner. 1964. Ammonium production in soil under waterlogged conditions as an index of nitrogen availability. Nature. 201: 951-952

Watt, R.F. 1966. Growth of black spruce stands after fertilization treatments, based on foliar analysis. Proc. Soc. Amer Foresters. p. 85-89

Weetman, G.F., H.H. Krause and E. Koller. 1976. Interprovincia forest fertilization program. Result of five year growth remeasurements in thirty installations. Fe;rtilized in 1969 remeasured in 1974. Environ. Can., Can. For. Serv. Tech. Rep. No. 16 .

Weetman, G.F., H.H. Krause, E. Koller and J.-M. Veilleux. 1987. Interprovincial forest fertilization trials 5- and 10-year results. For. Chron. 63: 184-192

Weetman, G.F., M.R. Roberge and C.H. Meng. 1980. Black spruce: 15 -year growth and microbiological responses to thinning and fertilization. Can. J. For. Res. 10: 502-509.

Weetman, G.F. and R. Fournier. 1982. Graphical diagnoses of lodgepole pine response to fertilization. Soil Sci. Soc. Am. J. 46 1280-1289.

Wollum, A.G. and C.B. Davey. 1975. Nitrogen accumulation transformation, and transport in forest soils. In: B. Bernier and C.H. Winget (eds.) Forest Soils and Forest Land Management. Univ. Laval Press, Quebec. p. 67-106. 